\title{
TEN AFSCHEID PROF. SNEYDERS DE VOGEL
}

Met ingang van I januari 1958 maakt Prof. Sneyders de Vogel geen deel meer uit van de redactie van Neophilologus. Met hem heeft de laatste oprichter van de onmiddelijke leiding van ons tijdschrift afgezien. Daarom alleen al spijt het ons, dat de heer Sneyders de Vogel gemeend heeft dit besluit te moeten nemen en, zoals dat heet, zijn plaats voor jongeren beschikbaar te stellen. Ook al is zijn eigen frisheid van geest en lichaam verbluffend, ook al blijft hij terdege op de hoogte van wat er juist onder de jongeren leeft, hij acht het noodzakelijk zijn taak aan anderen over te dragen.

De redactieleden blijft dientengevolge niets anders over dan deze gedachte te eerbiedigen en te aanvaarden. $Z_{i j}$ doen dit echter niet zonder spijt: zij zullen immers in hem niet alleen een figuur missen, die door zijn nooit verflauwende en sinds jaren waakzame aandacht de ontwikkelingsgang van Neophilologus nauwkeurig kende en de noodzakelijke mate van continuiteit in de leiding als het ware door zijn aanwezigheid waarborgde. Met Sneyders de Vogel verdwijnt ook een geleerde van naam uit de redactie, een man die zijn leven aan de wetenschap heeft gewijd en het grote voorrecht geniet daarvan tot op hoge leeftijd de vruchten te mogen plukken. En ten slotte - moet nog opgemerkt worden, dat hier niet het onbelangrijkste volgt? - zal de redactie niet meer kunnen genieten van zijn blijmoedige levendigheid, van het onverstoorbare natuurlijke evenwicht waarmede hij de vergaderingen leidde. Dank zij hem was de stemming altijd opgewekt en zo zich al eens netelige vraagstukken voordeden, dan werden deze door hem bijna zonder inspanning en zeker zonder spanning tot een bevredigend einde gebracht.

Overtuigd van zijn menselijke en wetenschappelijke dignitas gunnen wij Sneyders de Vogel gaarne een groter otium dan hij tot nu toe had. Wij zullen het dus verder zonder hem moeten doen en kunnen alleen maar hopen, dat hij nog lange jaren gelegenheid zal hebben de voortzetting van zijn werk in Neophilologus mede te beleven en te waarderen.

De Redactie stelt er prijs op van deze gelegenheid gebruik te maken om Dr. J. Engels in haar midden welkom te heten. Zij is er verheugd over, dat hij in den vervolge een deel van zijn werkzaamheden aan Neophilologus zal willen wijden, en houdt zich ervan overtuigd dat deze het tijdschrift ten goede zullen komen. 